\title{
ANALISIS SENDI PLASTIS LOKAL PADA PUSHOVER KELOMPOK TIANG PANCANG
}

\author{
Bagas Putraloka ${ }^{1}$, Gregorius Sandjaja ${ }^{2}$, dan Amelia Yuwono ${ }^{3}$ \\ ${ }^{1}$ Program Studi Sarjana Teknik Sipil, Universitas Tarumanagara, Jl. Letjen S. Parman No.1 Jakarta \\ bagas.325150033@stu.untar.ac.id \\ ${ }^{2}$ Program Studi Sarjana Teknik Sipil, Universitas Tarumanagara, Jl. Letjen S. Parman No.1 Jakarta \\ gregoriuss@ft.untar.ac.id \\ ${ }^{3}$ Program Studi Sarjana Teknik Sipil, Universitas Tarumanagara, Jl. Letjen S. Parman No.1 Jakarta \\ amelia7745@yahoo.com
}

Masuk: 15-01-202, revisi: 29-04-2020, diterima untuk diterbitkan: 05-05-2020

\begin{abstract}
Foundation is part of an engineering system which forwards the load supported by the foundation and its own weight into underneath the rock and the soil.Based on technical aspects and implementation it can be classified into pile and bore pile.Based on number piles divided into single pile and group piles.Group pile is a group of piles structured relatively close and connected with the pile cap at the top. Because of enhancement of earthquake acceleration on certain area on SNI 1726:2012, Analysis of group pile is needed on area with enhancement of earthquake acceleration. The collection data method is obtained by collecting data from the project by form bore $\log$ and laboratory test meanwhile for data analysis method using basic theory used as a reference for learning pushover analysis which refers fom ATC-40. By doing pushover analysis on a group pile, Performence of group pile can be known as Performence Point which will be compared to each of the pile configurations. And the result from this research is more the number of piles on the configuration being modeled, the result is the value of performence point getting higher, because of the lateral force will be tested be more higher.
\end{abstract}

Keywords: foundation; group pile; performance level, spectrum capacity method, pushover analysis

\begin{abstract}
ABSTRAK
Fondasi ialah bagian dari suatu sistem rekayasa yang meneruskan beban yang ditopang oleh fondasi dan beratnya sendiri ke dalam tanah dan batuan yang terletak di bawahnya. berdasarkan segi teknis pelaksanaan dapat diklasifikasikan menjadi tiang pancang dan tiang bor. Berdasarkan jumlah tiang ada dua macam yaitu tiang tunggal dan tiang kelompok, tiang kelompok adalah sekumpulan tiang yang dipasang secara relatif berdekatan yang dihubungkan bagian atasnya dengan pile cap. Karena adanya peningkatan percepatan gempa di daerah tertentu pada SNI 1726:2012, perlu dilakukan analisis terhadap kelompok tiang di daerah yang terkena peningkatan percepatan gempa. Metode pengumpulan data dilakukan dengan mengumpulkan data-data yang berasal dari proyek berupa hasil boring log dan hasil tes laboratorium sedangkan untuk Metode analisis data digunakan teori dasar yang digunakan sebagai acuan pembelajaran dalam melakukan analisis Pushover yang mengacu pada ATC-40. Dengan melakukan analisis pushover pada suatu kelompok tiang, tingkat kinerja suatu kelompok tiang dapat diketahui berupa nilai Performance Point yang akan dibandingkan setiap konfigurasi tiang. Dan hasil yang didapat dalam penelitian ini adalah semakin banyak jumlah tiang dalam konfigurasi yang dimodelkan maka nilai performence point pun semakin tinggi, karena gaya lateral yang diuji akan semakin tinggi.
\end{abstract}

Kata kunci: fondasi; kelompok tiang; tingkat kinerja; metode spektrum kapasitas; analisis pushover

\section{PENDAHULUAN}

\section{Latar belakang}

Dalam suatu pekerjaan konstruksi pasti terdapat struktur fondasi, fondasi menjadi salah satu faktor penting yang membuat suatu bangunan dapat kokoh berdiri. Fondasi memiliki fungsi untuk menahan beban aksial dan lateral yang diteruskan kebagian tanah pendukung bangunan tersebut. tiang kelompok adalah sekumpulan tiang yang dipasang secara relatif berdekatan yang dihubungkan bagian atasnya dengan pile cap. Tiang kelompok biasanya digunakan apabila tiang tunggal tidak dapat menahan beban dan gaya yang terlalu besar yang dihasilkan dari bagian struktur bangunan yang tepat berada dibagian atas struktur fondasi. Diberlakukannya SNI 1726:2012 yang menggantikan SNI 1726:2002 sehingga ada daerah tertentu yang mengalami kenaikan percepatan gempa sehingga gaya gempa yang diterima fondasi meningkat. Oleh karena itu perlu dilakukan analisis terhadap suatu kelompok 
tiang dengan berbagai percepatan gempa pada kondisi elastik maupun tidak elastik, salah satunya adalah dengan analisis statik non linier atau analisis pushover. Analisis pushover adalah prosedur analisis untuk mengetahui keruntuhan suatu bangunan dengan memberikan suatu pola beban statik tertentu dalam arah lateral yang besarnya akan ditingkatkan secara bertahap sampai struktur tersebut mencapai target displacement tertentu atau mencapai pola keruntuhan tertentu. Dari hasil analisis pushover terhadap suatu kelompok tiang tersebut dihasilkan kurva yang menghubungkan antara base shear dan roof displacement atau disebut kurva kapasitas. Dari kurva kapasitas tersebut dapat dilihat perilaku suatu kelompok tiang dari kondisi elastis sampai plastis hingga mengalami kegagalan. Dengan adanya kurva kapasitas yang diperoleh, kita dapat melihat tingkat kinerja suatu kelompok tiang berdasarkan metode spektrum kapasitas berdasarkan peraturan ATC-40 dan Pushover Analysis of Underground Structures. Didalam pembahasan kali ini ditemui beberapa batasan masalah, yaitu data tanah diambil di di daerah Banten (Tangerang Selatan), dalam permodelan dibantu dengan program berbasis geoteknik, menggunkan konfigurasi kelompok tiang 4,6,9,12 dan 16 tiang, gaya yang diterima hanya gaya lateral dan jenis tanah dimodifikasi mengikuti SNI 1726 : 2012. Tujuan dari penelitian ini, yaitu ingin mengetahui besarnya gaya lateral maksimum yang dapat diterima kelompok tiang dan besarnya displacement pada kondisi elastik, dan mengetagui tingkat kinerja struktur pada tiang melalui analisis pushover menurut peraturan ATC-40 dan Pushover Analysis of Underground Structures.

\section{Analisis statik non-linier (pushover analysis)}

Analisa statik nonlinier merupakan prosedur analisa untuk mengetahui perilaku keruntuhan suatu bangunan terhadap gempa, dikenal pula sebagai analisa pushover atau analisa beban dorong statik. Kecuali untuk suatu struktur yang sederhana, maka analisa ini memerlukan komputer program untuk dapat merealisasikannya pada bangunan nyata. Analisa dilakukan dengan memberikan suatu pola beban lateral statik pada struktur, yang kemudian secara bertahap ditingkatkan dengan faktor pengali sampai satu target perpindahan lateral dari suatu titik acuan tercapai. Biasanya titik tersebut adalah titik pada atap, atau lebih tepat lagi adalah pusat massa atap. Analisa pushover menghasilkan kurva pushover, kurva yang menggambarkan hubungan antara gaya geser dasar (V) versus perpindahan titik acuan pada atap (D) . Pada proses pushover, struktur didorong sampai mengalami leleh disatu atau lebih lokasi di struktur tersebut. Kurva kapasitas akan memperlihatkan suatu kondisi linier sebelum mencapai kondisi leleh dan selanjutnya berperilaku non-linier. Kurva pushover dipengaruhi oleh pola distribusi gaya lateral yang digunakan sebagai beban dorong. Tujuan analisa pushover adalah untuk memperkirakan gaya maksimum dan deformasi yang terjadi serta untuk memperoleh informasi bagian mana saja yang kritis. Berikut gambar 1 dibawah ini adalah contoh kurva yang akan diibentuk melalui metode pushover analysis yang dibantu oleh program berbasis geoteknik. (Sumber Dewobroto, W. 2005)

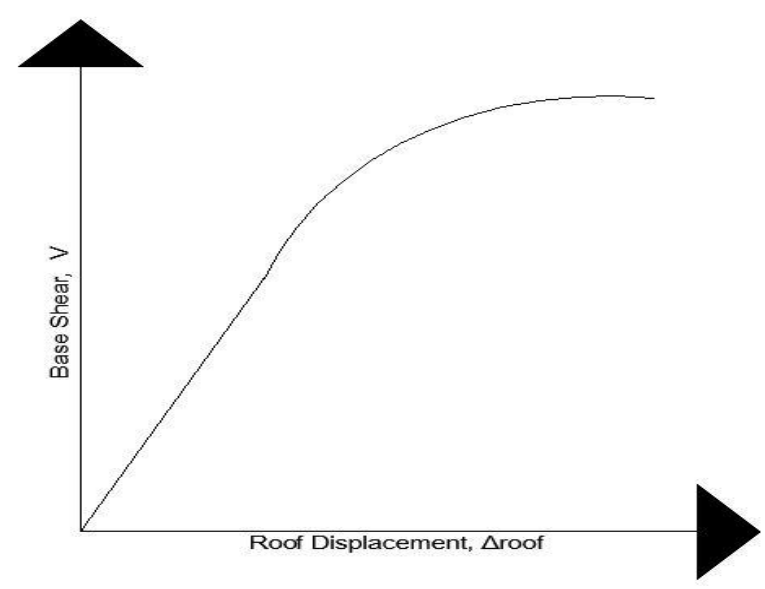

Gambar 1. Kurva pushover (Sumber: ATC-40, $1996: 8-12$ )

\section{Tingkat kinerja struktur metode $A T C-40$}

Dalam metode $A T C-40$, tingkat kinerja struktur ditentukan dengan menggunakan metode spektrum kapasitas (capacity-spectrum), yaitu dengan memplotkan demand respons spektrum dan kurva kapasitas dalam satu format antara spektral percepatan dan spektral perpindahan atau disebut sebagai format Acceleration-Displacement Response Spectra (ADRS).

Kurva kapasitas (capacity-curve) diperoleh dari analisis pushover, yaitu analisis statik nonlinier dengan memberikan beban lateral statik tertentu pada struktur yang kemudian ditingkatkan secara bertahap hingga struktur 
mencapai suatu batas tertentu atau mengalami kegagalan struktur. Respons struktur terhadap beban lateral tersebut dicatat dan dibuat kurva hubungan antara gaya geser dasar, " $V$ " dan perpindahan pada atap, " $\Delta_{\text {atap }}$ ". Kurva tersebut-lah yang disebut sebagai kurva kapasitas.

Kurva kapasitas menggambarkan kekuatan struktur yang besarnya sangat tergantung dari kemampuan deformasi masing-masing elemen struktur. Untuk mengubah kurva kapasitas ke dalam format $A D R S$ atau menjadi spektrum kapasitas diperlukan pemahaman tentang hubungan faktor partisipasi modal, modal koefisien massa, dan perpindahan bangunan. Untuk mengubah kurva kapasitas ke dalam format ADRS digunakan persamaan.

$$
\begin{aligned}
S_{a} & =\frac{V / W}{\alpha_{1}} \\
S_{d} & =\frac{\Delta_{\text {roof }}}{P F_{1} \phi_{\text {roof } .1}}
\end{aligned}
$$

dengan $\mathrm{V}=$ gaya geser dasar $(\mathrm{kN}), \mathrm{W}=$ berat tiang $(\mathrm{kN}), \alpha_{1}=$ modal koefisien massa pada mode pertama, $\Delta_{\text {roof }}=$ perpindahan atap $(\mathrm{m}), \mathrm{PF}=$ faktor partisipasi modal pada mode pertama. Demand spektrum diperoleh dengan mengubah respons spektrum yang biasanya dinyatakan dalam spektra percepatan " $S_{a}$ " dan periode " $T$ " menjadi format $A D R S\left(S_{a}, S_{d}\right)$ dengan menggunakan persamaan

$$
S_{d}=\frac{T^{2}}{4 \pi^{2}} S_{a} \cdot(g)
$$

dengan $\mathrm{Sa}=$ spektra percepatan $(\mathrm{m}), \mathrm{Sd}=$ spektra perpindahan $(\mathrm{g}), \mathrm{g}=$ percepatan $\operatorname{gravitasi}\left(9.81 \mathrm{~m} / \mathrm{s}^{2}\right), \mathrm{T}=$ periode getar fundamental (detik)

Selanjutnya, grafik spektrum kapasitas dan spektrum demand digambarkan dalam satu grafik ADRS. Dalam grafik tersebut akan terjadi perpotongan antara spektrum kapasitas dan spektrum demand. Titik perpotongan tersebut disebut sebagai titik kinerja atau performance point. Redaman yang terjadi saat struktur terkena gerakan gempa pada keadaan inelastik dapat dilihat pada redaman viscous yang melekat pada struktur dan redaman histerestik.

Redaman histerestik (hysteretic damping) berhubungan dengan area di dalam loop kurva gaya dan perpindahan akibat gaya gempa. Redaman histerestik ini dapat mewakili redaman viscous ekuivalen. Dalam ATC-40 redaman viscous ekuivalen dirumuskan dengan persamaan

$$
\begin{aligned}
\beta_{0} & =\frac{63.7(\text { ay } \cdot d p i-d y \cdot a p i)}{\text { api.dpi }} \\
\beta_{e q} & =\boldsymbol{\beta} 0+5 \\
S R_{A} & =\frac{3.21-0.68 \ln (\boldsymbol{\beta e q})}{2.12} \\
S R_{V} & =\frac{2.31-0.41 \ln (\boldsymbol{\beta e q})}{1.65}
\end{aligned}
$$

dengan $\beta_{0}=$ redaman histerestis yang mewakili redaman viscous ekuivalen, $\beta_{e q}=$ redaman viscous ekuivalen struktur, 0.05 = redaman yang melekat pada struktur (redaman awal)

Efensiensi tiang pun harus turut diperhitungkan dalam perthitungan tiang kelompok, menurut formula ConverseLabarre efesiensi tiang dapat dihitung dengan rumus, sebagai berikut:

$$
E_{g} \quad=1-\left(\frac{(n-1) m+(m-1) n}{90 \cdot m \cdot n}\right) \emptyset
$$

dengan $n=$ jumlah tiang pada deretan baris, $m=$ jumlah tiang pada deretan kolom, $\varnothing=\operatorname{arc} \tan (\mathrm{D} / \mathrm{s}), \mathrm{s}=\mathrm{jarak}$ antar tiang, $\mathrm{D}=$ diameter atau sisi tiang 
Tabel 1. Nilai minimum yang diizinkan untuk $S R_{A}$ dan $S R_{V}$

\begin{tabular}{ccc}
\hline $\begin{array}{c}\text { Structural } \\
\text { Behavior Type }\end{array}$ & $S R_{A}$ & $S R_{V}$ \\
\hline Type A & & \\
Type B & 0.33 & 0.5 \\
Type C & 0.44 & 0.56 \\
\hline
\end{tabular}

Tabel 2. Batasan simpangan pada tingkat kinerja struktur (Sumber: ATC-40, 1996 : 11-4)

\begin{tabular}{|c|c|c|c|c|}
\hline Antar Tingkat & $\begin{array}{l}\text { Immediate } \\
\text { Occupancy }\end{array}$ & Damage Control & Life Safety & $\begin{array}{c}\text { Structural } \\
\text { Stability }\end{array}$ \\
\hline $\begin{array}{c}\text { Simpangan Total } \\
\text { Maksimum }\end{array}$ & 0,01 & $0,01-0,02$ & 0,02 & $0,33 V_{i} / P_{i}$ \\
\hline $\begin{array}{c}\text { Simpangan } \\
\text { Inelastis } \\
\text { Maksimum }\end{array}$ & 0,005 & $0,005-0,015$ & $\begin{array}{c}\text { Tidak ada } \\
\text { Batasan }\end{array}$ & $\begin{array}{c}\text { Tidak ada } \\
\text { Batasan }\end{array}$ \\
\hline
\end{tabular}

Tabel 3 Storey drift limits at different performance levels and damage states

(Sumber: Pushover Analysis of Underground Structures, 2014 : 426)

\begin{tabular}{ccc}
\hline Performance Level & Damage State & Storey Drift \\
\hline Fully operational, immediate occupancy & No Damage & $<0.2 \%$ \\
Operational, damage control, moderate & Repairable & $<0.5 \%$ \\
Life safe-damage state & Irreparable & $<1.5 \%$ \\
Near collapse, limited safety, hazard reduced & Severe & $<2.5 \%$ \\
Collapse & & $>2.5 \%$ \\
\hline
\end{tabular}




\section{METODE PENELITIAN}

\section{Metode Pengumpulan Data}

Metode yang digunakan dalam pengumpulan data-data yang akan dipakai adalah dengan pengumpulan data dari proyek. Pada studi ini, data tanah akan dianalisis mengikuti SNI 1726:2012 yang berlokasi di daerah Serpong, Tangerang Selatan. Data tanah yang dikumpulkan berupa boring log dan hasil tes laboratorium. Data tanah tersebut merupakan laporan penyelidikan tanah pada daerah tersebut.

\section{Metode Analisis Data}

Sebelum dilakukannya analisis data, dilakukan pembelajaran atau studi tentang teori-teori dasar yang berhubungan dengan topik pembahasan dalam penelitian yang akan dilakukan. Teori dasar yang digunakan sebagai acuan pembelajaran dapat dicari berdasarkan berbagai macam sumber, seperti jurnal, karya ilmiah, buku referensi yang akan berguna untuk mendapatkan rumus-rumus atau persamaan. Dalam melakukan analisis pushover mengacu pada $A T C-40$.

\section{HASIL DAN PEMBAHASAN}

Setelah dilakukan analisis pushover, maka kita bisa mendapatkan beban maksimum untuk tiap kelompok tiang dan mendapatkan kurva kapasitas, kemudian diubah menjadi kurva spektrum kapasitas. Dari kurva tersebut kita bisa mendapat performance point dan pile drift ratio yang akan digunakan untuk menentukan tingkat kinerja kelompok tiang., berikut dibawah ini adalah konfigurasi tiang kelompok yang dipakai dalam penelitian ini.
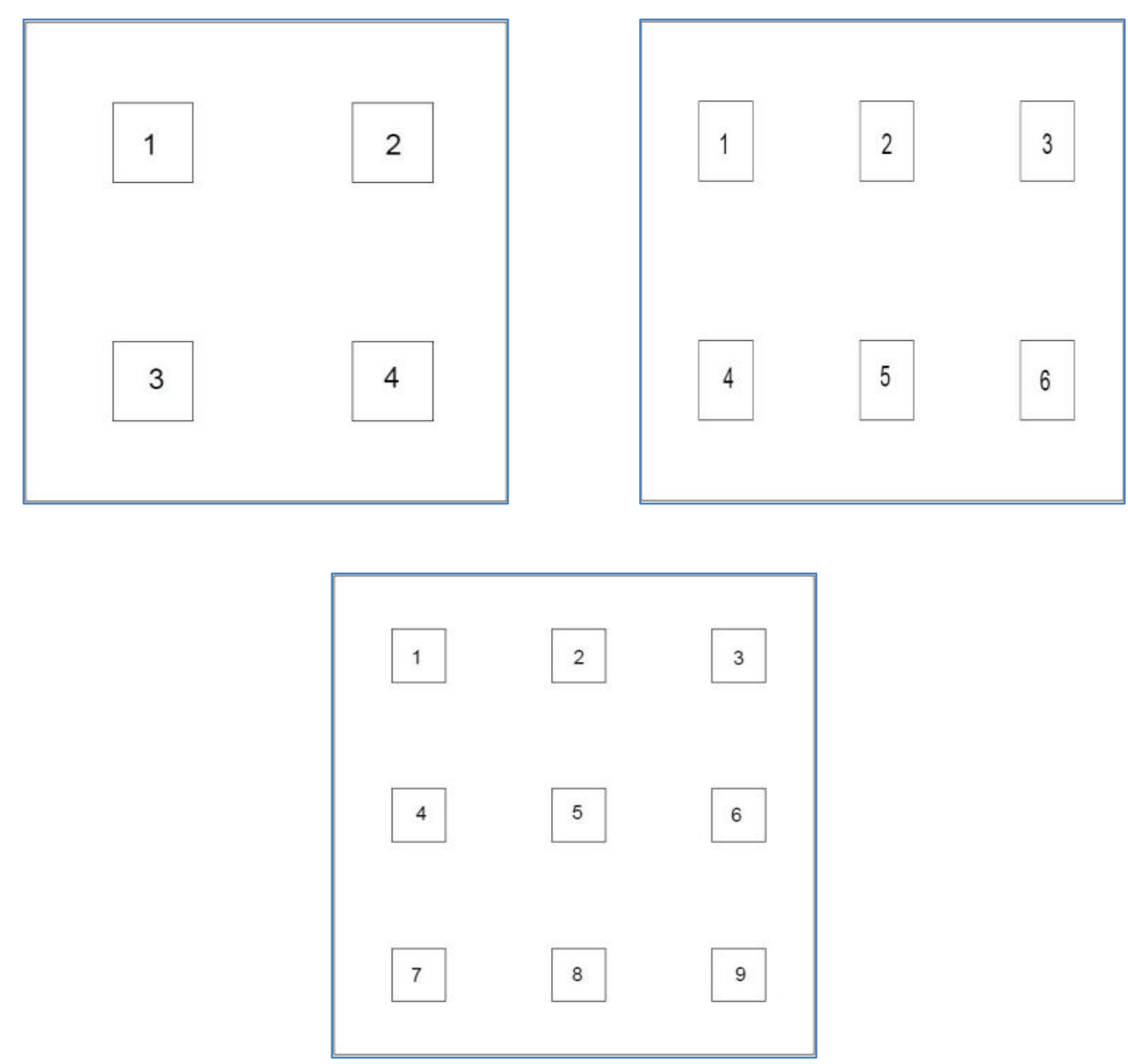

Gambar 2. Macam konfigurasi tiang kelompok 4, 6, dan 9 

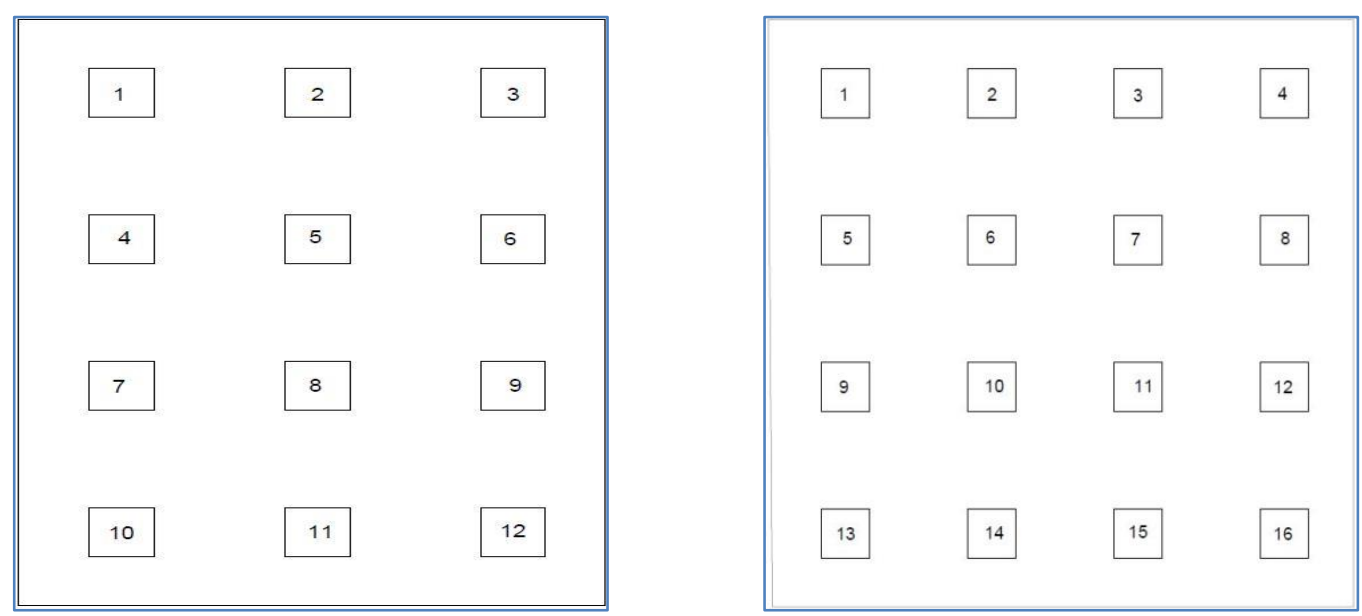

Gambar 3. Macam konfigurasi tiang kelompok 12 dan 16

Setelah menentukan tiang kelompok maka struktur tiang ini akan diuji menggunakan program berbasis geoteknik dengan memasukan beban secara lateral menggunakan metode analisis pushover sampai mengalaimi displacement tertentu yang diiginkan. Gambar 4 merupakan kurva hasil dari analalisis menggunakan program berbasis geoteknik yang disebut dengan kurva kapasitas (capacity curve).

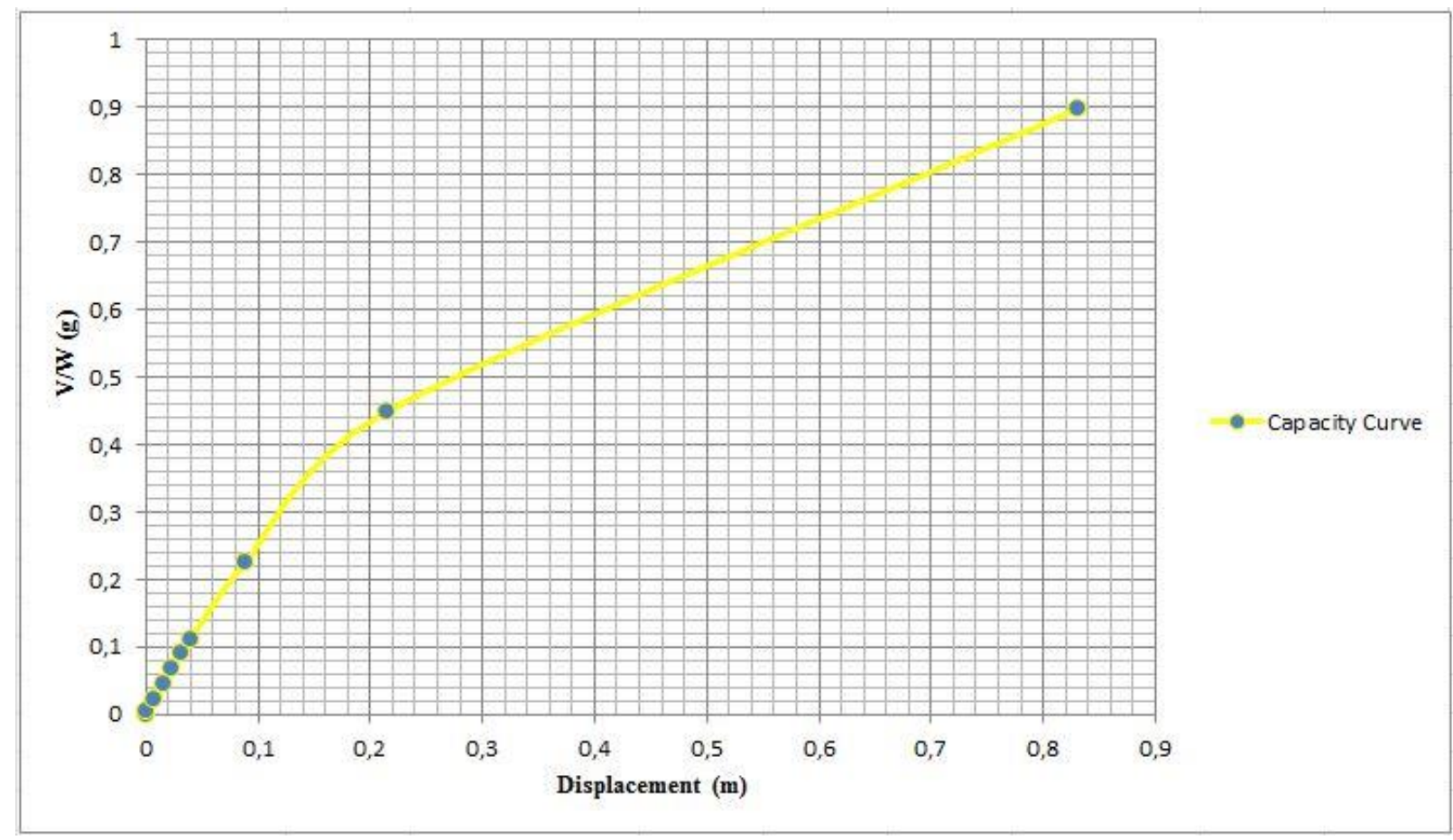

Gambar 4. Kurva (capacity curve) dari hasil program berbasis geoteknik

Setelah itu kurva kapasitas akan diubah menjadi format Acceleration-Displacement Response Spectra (ADRS) maka akan didapatkan nilai performence point setiap konfigurasi tiang kelompok yang nantinya akan diacukan terhadap Tabel 2 Batasan Simpangan pada Tingkat Kinerja Struktur dan Tabel 3 Storey Drift Limits at Different Performance Levels and Damage States. 


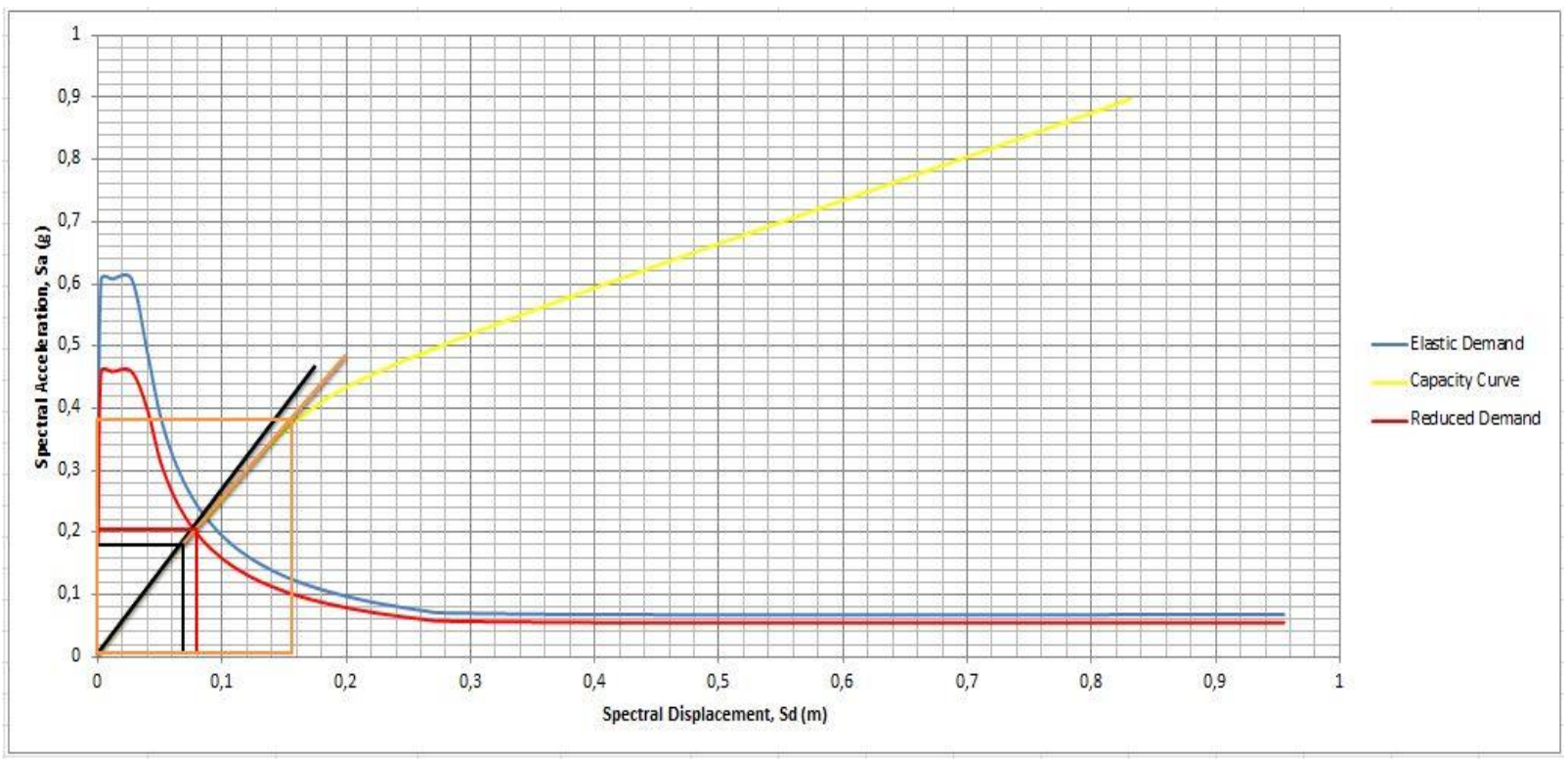

Gambar 5. Kurva Acceleration-Displacement Response Spectra (ADRS)

Setelah semua tiang diuji menggunakan program berbasis geoteknik dan mendapat nilai kinerja struktur (performence point) menggunakan metode analisi pushover yang mengacu pada ATC -40 , Tabel 4 dan 5 merupakan hasil rangkuman dari penelitian ini.

Tabel 4. Hasil analisis Semi Fixed Head

\begin{tabular}{|c|c|c|c|c|c|c|c|}
\hline $\begin{array}{l}\text { Jumlah } \\
\text { Tiang }\end{array}$ & $\begin{array}{l}\text { Tipe } \\
\text { Tiang }\end{array}$ & $\begin{array}{c}\text { Beban } \\
(\mathrm{kN})\end{array}$ & $\begin{array}{l}\text { Fixed and } \\
\text { Length }(\mathrm{m})\end{array}$ & $\begin{array}{l}\text { Performance } \\
\quad \text { Point }\end{array}$ & $\begin{array}{l}\text { Pile Drift } \\
\text { Ratio }\end{array}$ & Kategori & Kesimpulan \\
\hline 4 & \multirow{3}{*}{ Elastik } & \multirow{3}{*}{10000} & \multirow{3}{*}{7,5} & \multirow{3}{*}{0,115} & \multirow{3}{*}{0,01466} & $0.01-0.02$ & Damage Control \\
\hline \multirow[t]{2}{*}{ Tiang } & & & & & & & \\
\hline & & & & & & $<1.5 \%$ & $\begin{array}{c}\text { Irreparable, Life safe- } \\
\text { damage state }\end{array}$ \\
\hline \multirow{3}{*}{$\begin{array}{c}6 \\
\text { Tiang } \\
\text { arah X }\end{array}$} & \multirow{3}{*}{ Elastik } & \multirow{3}{*}{10000} & \multirow{3}{*}{7,5} & \multirow{3}{*}{0,15} & \multirow{3}{*}{0,02} & $0.01-0.02$ & Damage Control \\
\hline & & & & & & & \\
\hline & & & & & & $<2.5 \%$ & $\begin{array}{c}\text { Severe, Near collapse, } \\
\text { limited safety, hazard } \\
\text { reduced }\end{array}$ \\
\hline \multirow{2}{*}{$\begin{array}{c}6 \\
\text { Tiang } \\
\text { arah Y }\end{array}$} & \multirow{2}{*}{ Elastik } & \multirow{2}{*}{10000} & \multirow{2}{*}{7,5} & \multirow{2}{*}{0,14} & \multirow{2}{*}{0,01866} & $0.01-0.02$ & Damage Control \\
\hline & & & & & & $<2.5 \%$ & $\begin{array}{c}\text { Severe, Near collapse, } \\
\text { limited safety, hazard } \\
\text { reduced }\end{array}$ \\
\hline \multirow[b]{2}{*}{$\begin{array}{c}9 \\
\text { Tiang }\end{array}$} & \multirow[b]{2}{*}{ Elastik } & \multirow[b]{2}{*}{12000} & \multirow[b]{2}{*}{7,5} & \multirow[b]{2}{*}{0,17} & \multirow[b]{2}{*}{0,1875} & $0.01-0.02$ & Damage Control \\
\hline & & & & & & $<2.5 \%$ & $\begin{array}{c}\text { Severe, Near collapse, } \\
\text { limited safety, hazard } \\
\text { reduced }\end{array}$ \\
\hline
\end{tabular}


Tabel 4. Hasil analisis Semi Fixed Head (lanjutan)

\begin{tabular}{|c|c|c|c|c|c|c|c|}
\hline $\begin{array}{l}\text { Jumlah } \\
\text { Tiang }\end{array}$ & $\begin{array}{l}\text { Tipe } \\
\text { Tiang }\end{array}$ & $\begin{array}{l}\text { Beban } \\
(\mathrm{kN})\end{array}$ & $\begin{array}{l}\text { Fixed and } \\
\text { Length }(\mathrm{m})\end{array}$ & $\begin{array}{l}\text { Performance } \\
\text { Point }\end{array}$ & $\begin{array}{l}\text { Pile Drift } \\
\quad \text { Ratio }\end{array}$ & Kategori & Kesimpulan \\
\hline \multirow[b]{2}{*}{$\begin{array}{l}12 \text { Tiang } \\
\operatorname{arah} X\end{array}$} & \multirow[b]{2}{*}{ Elastik } & \multirow[b]{2}{*}{14000} & \multirow[b]{2}{*}{7,5} & \multirow[b]{2}{*}{0,18} & \multirow[b]{2}{*}{0,0195} & $0.01-0.02$ & Damage Control \\
\hline & & & & & & $<2.5 \%$ & $\begin{array}{c}\text { Severe, Near collapse, } \\
\text { limited safety, hazard } \\
\text { reduced }\end{array}$ \\
\hline \multirow[b]{2}{*}{$\begin{array}{l}12 \text { Tiang } \\
\text { arah Y }\end{array}$} & \multirow[b]{2}{*}{ Elastik } & \multirow[b]{2}{*}{15000} & \multirow[b]{2}{*}{7,5} & \multirow[b]{2}{*}{0,185} & \multirow[b]{2}{*}{0,0185} & $0.01-0.02$ & Damage Control \\
\hline & & & & & & $<2.5 \%$ & $\begin{array}{c}\text { Severe, Near collapse, } \\
\text { limited safety, hazard } \\
\text { reduced }\end{array}$ \\
\hline \multirow[b]{2}{*}{16 Tiang } & \multirow[b]{2}{*}{ Elastik } & \multirow[b]{2}{*}{16000} & \multirow[b]{2}{*}{7,5} & \multirow[b]{2}{*}{0,195} & \multirow[b]{2}{*}{0,02} & $0.01-0.02$ & Damage Control \\
\hline & & & & & & $<2.5 \%$ & $\begin{array}{c}\text { Severe, Near collapse, } \\
\text { limited safety, hazard } \\
\text { reduced }\end{array}$ \\
\hline \multicolumn{8}{|c|}{ Tabel 5. Hasil analisis Fixed Head } \\
\hline $\begin{array}{c}\text { Jumlah } \\
\text { Tiang }\end{array}$ & $\begin{array}{l}\text { Tipe } \\
\text { Tiang }\end{array}$ & $\begin{array}{c}\text { Beban } \\
(\mathrm{kN})\end{array}$ & $\begin{array}{l}\text { Fixed and } \\
\text { Length }(\mathrm{m})\end{array}$ & $\begin{array}{c}\text { Performance } \\
\text { Point }\end{array}$ & $\begin{array}{l}\text { Pile Drift } \\
\text { Ratio }\end{array}$ & Kategori & Kesimpulan \\
\hline \multirow[b]{2}{*}{4 Tiang } & \multirow[b]{2}{*}{ Elastik } & \multirow[b]{2}{*}{20000} & \multirow[b]{2}{*}{7,5} & \multirow[b]{2}{*}{0,08} & \multirow[b]{2}{*}{0,01133} & $0.01-0.02$ & Damage Control \\
\hline & & & & & & $<1.5 \%$ & $\begin{array}{c}\text { Irreparable, Life safe- } \\
\text { damage state }\end{array}$ \\
\hline \multirow{2}{*}{$\begin{array}{l}6 \text { Tiang } \\
\operatorname{arah} X\end{array}$} & \multirow{2}{*}{ Elastik } & \multirow{2}{*}{30000} & \multirow{2}{*}{7,5} & \multirow{2}{*}{0,125} & \multirow{2}{*}{0,01667} & $0.01-0.02$ & Damage Control \\
\hline & & & & & & $<1.5 \%$ & $\begin{array}{c}\text { Irreparable, Life safe- } \\
\text { damage state }\end{array}$ \\
\hline \multirow{2}{*}{$\begin{array}{l}6 \text { Tiang } \\
\text { arah Y }\end{array}$} & \multirow{2}{*}{ Elastik } & \multirow{2}{*}{30000} & \multirow{2}{*}{7,5} & \multirow{2}{*}{0,1} & \multirow{2}{*}{0,01333} & $0.01-0.02$ & Damage Control \\
\hline & & & & & & $<1.5 \%$ & $\begin{array}{c}\text { Irreparable, Life safe- } \\
\text { damage state }\end{array}$ \\
\hline & & & & & & $0.01-0.02$ & Damage Control \\
\hline 9 Tiang & Elastik & 32000 & 7,5 & 0,125 & 0,016 & $<2.5 \%$ & $\begin{array}{c}\text { Severe, Near collapse, } \\
\text { limited safety, hazard } \\
\text { reduced }\end{array}$ \\
\hline
\end{tabular}


Tabel 5. Hasil analisis Fixed Head (lanjutan)

\begin{tabular}{|c|c|c|c|c|c|c|c|}
\hline $\begin{array}{c}\text { Jumlah } \\
\text { Tiang }\end{array}$ & $\begin{array}{c}\text { Tipe } \\
\text { Tiang }\end{array}$ & $\begin{array}{c}\begin{array}{c}\text { Beban } \\
(\mathrm{kN})\end{array} \\
\end{array}$ & $\begin{array}{l}\text { Fixed and } \\
\text { Length }(\mathrm{m})\end{array}$ & $\begin{array}{c}\text { Performance } \\
\text { Point }\end{array}$ & $\begin{array}{c}\text { Pile Drift } \\
\text { Ratio }\end{array}$ & Kategori & Kesimpulan \\
\hline \multirow[b]{2}{*}{$\begin{array}{l}12 \text { Tiang } \\
\operatorname{arah} X\end{array}$} & \multirow[b]{2}{*}{ Elastik } & \multirow[b]{2}{*}{36000} & \multirow[b]{2}{*}{7,5} & \multirow[b]{2}{*}{0,14} & \multirow[b]{2}{*}{0,0186} & $0.01-0.02$ & Damage Control \\
\hline & & & & & & $<2.5 \%$ & $\begin{array}{c}\text { Severe, Near collapse, } \\
\text { limited safety, hazard } \\
\text { reduced }\end{array}$ \\
\hline \multirow{2}{*}{$\begin{array}{l}12 \text { Tiang } \\
\text { arah Y }\end{array}$} & \multirow[b]{2}{*}{ Elastik } & \multirow[b]{2}{*}{36000} & \multirow[b]{2}{*}{7,5} & \multirow[b]{2}{*}{0,125} & \multirow{2}{*}{0,0667} & $0.01-0.02$ & Damage Control \\
\hline & & & & & & $<2.5 \%$ & $\begin{array}{l}\text { Severe, Near collapse, } \\
\text { limited safety, hazard } \\
\text { reduced }\end{array}$ \\
\hline \multirow[b]{2}{*}{16 Tiang } & \multirow[b]{2}{*}{ Elastik } & \multirow[b]{2}{*}{40000} & \multirow[b]{2}{*}{7,5} & \multirow[b]{2}{*}{0,15} & \multirow{2}{*}{0,02} & $0.01-0.02$ & Damage Control \\
\hline & & & & & & $<2.5 \%$ & $\begin{array}{c}\text { Severe, Near collapse, } \\
\text { limited safety, hazard } \\
\text { reduced }\end{array}$ \\
\hline
\end{tabular}

Berikut hasil cross check menggunakan program EFF GROUP (lateral), menggunakan contoh konfigurasi 4 tiang kondisi (Semi Fixed Head)

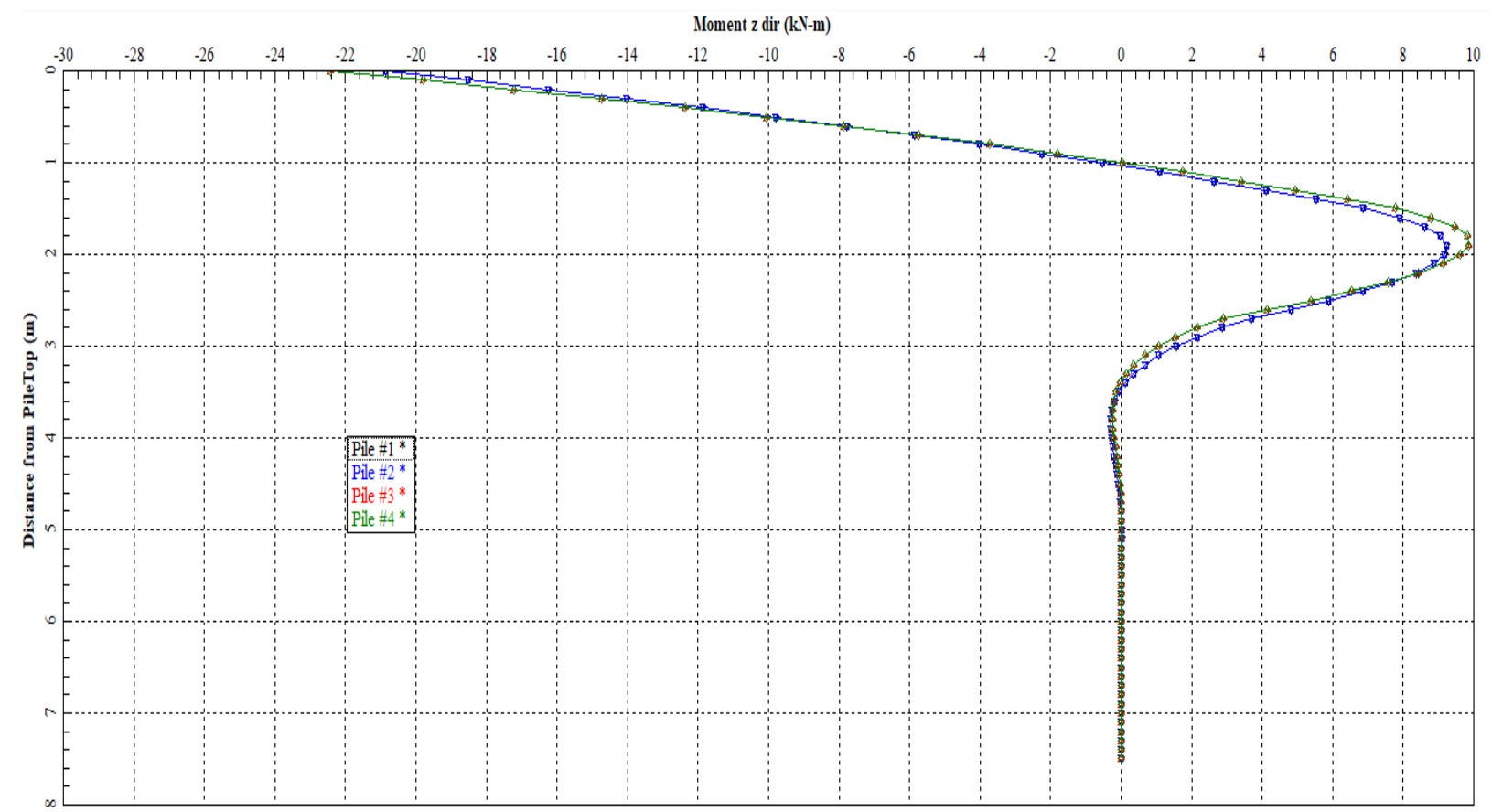

Gambar 6. Bending moment saat load $100 \mathrm{kN}$ 


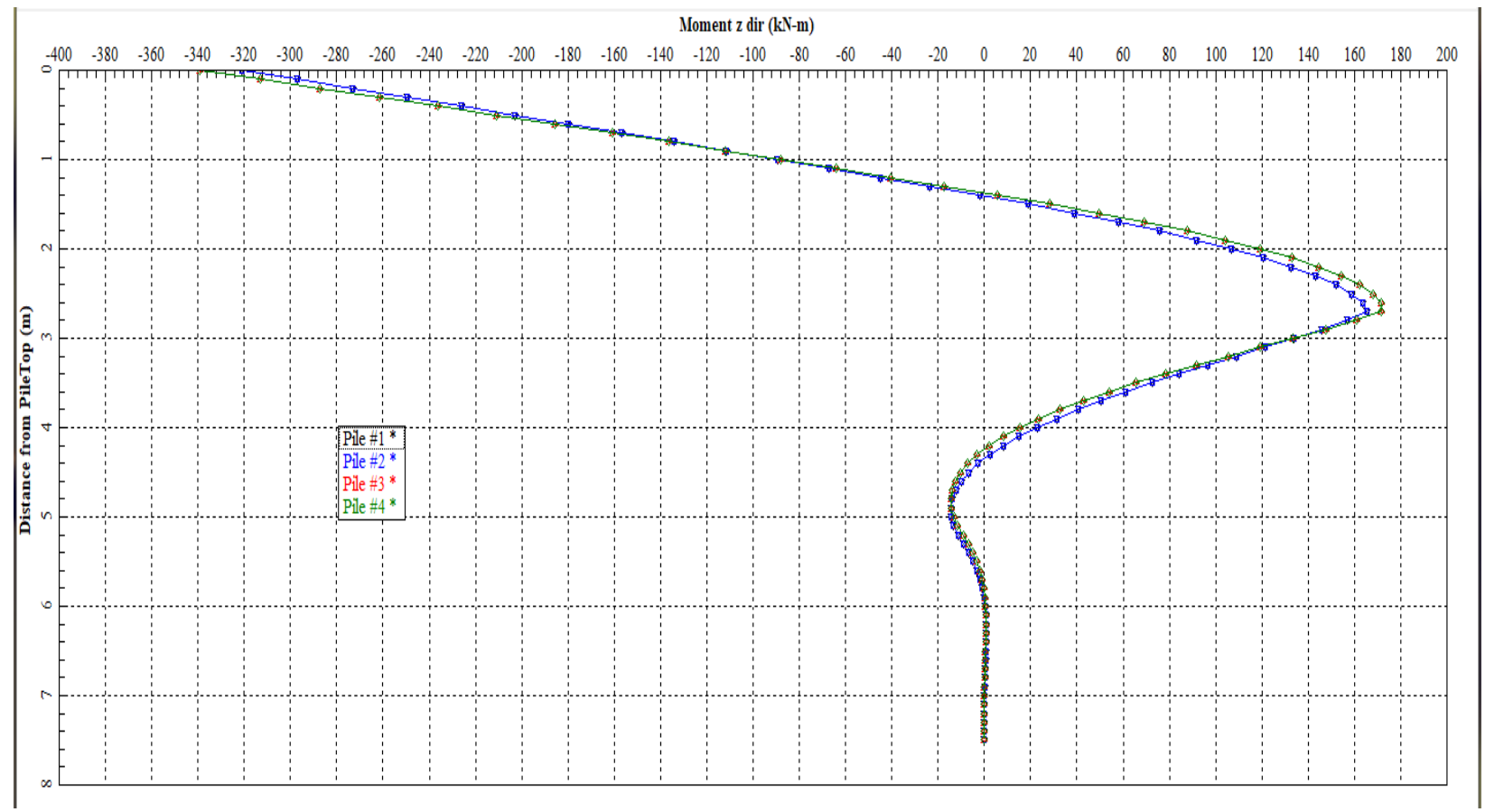

Gambar 7. Bending moment saat load 1000 kN

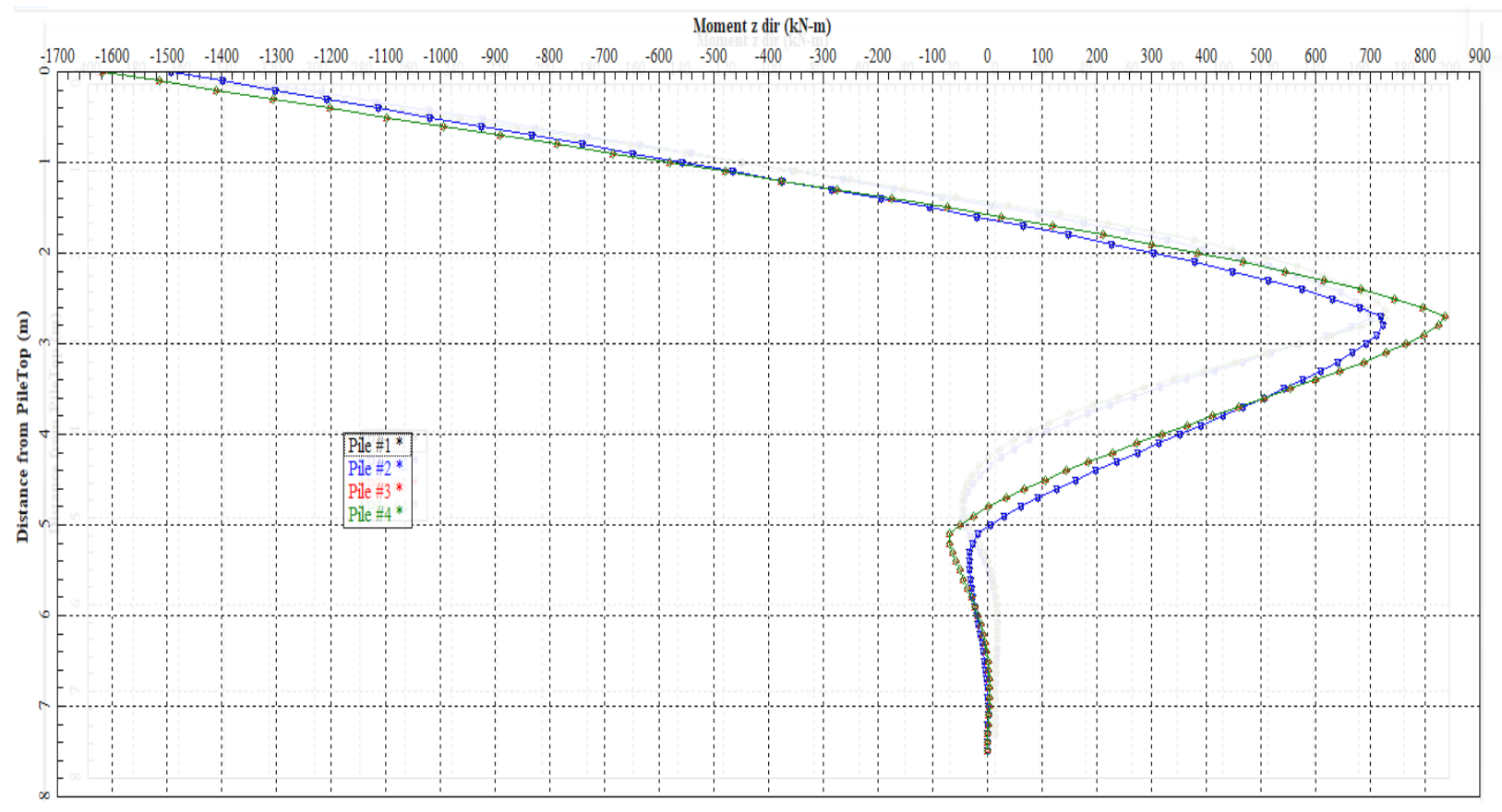

Gambar 8. Bending moment saat load $2000 \mathrm{kN}$

Dan hasil dari cross check menggunakan program EFF GROUP (lateral), menggunakan contoh konfigurasi 4 tiang kondisi (Semi Fixed Head) tidak terlalu berbeda dimana bending moment saat pengujian $2000 \mathrm{kN}$ menggunakan program EFF GROUP (lateral) sudah mencapai nilai bending moment maksimum sedangkan saat menggunakan program PLAXIS 3D dibuthkan beban lateral sebsar $2250 \mathrm{kN}$ untuk mencapai nilai bending moment maksimum. 


\section{KESIMPULAN DAN SARAN}

Berdasarkan analisis yang dilakukan, didapatkan beberapa kesimpulan sebagai berikut:

1. Berdasarkan hasil studi, semakin banyak jumlah tiang dalam suatu kelompok tiang makan semakin besar beban lateral maksimum yang dapat diterima tiap tiang pada suatu kelompok tiang untuk kondisi elastik.

2. Berdasarkan hasil dari program geoteknik yang dianalisis semakin banyak jumlah tiang maka semakin tinggi juga nilai pile drift ratio yang didapatkan dikarenakan semakin banyak tiang maka semakin besar beban lateral yang dapat diterima yang menyebabkan terjadinya pola kegagalan pada tanah (failure point).

3. Berdasarkan hasil program geoteknik yang dianalisis berdasarkan nilai Bending Moment dapat disimpulkan semakin dekat point load dalam bentuk beban lateral dengan sebuah pile maka semakin besar pula kemungkinan pile tersebut mengalami patahan dengan beban load yang masih kecil.

4. Berdasarkan hasil rangkuman didapat kesimpulan:

Untuk kondisi Semi Fixed Head:

Tabel 6. Rangkuman hasil dari bending moment kondisi semi fixed head

\begin{tabular}{cccc}
\hline Jumlah Tiang & Rata-rata Kedalaman $(\mathrm{m})$ & $\begin{array}{c}\text { Rata-rata Load } \\
\text { Maksimum }(\mathrm{kN})\end{array}$ & $\begin{array}{c}\text { Rata-rataBending Moment } \\
\text { Maksimum }(\mathrm{kNm})\end{array}$ \\
\hline 4 Tiang & 4,675 & 2250 & 457,5 \\
6 Tiang arah X & 6.066 & 3583,333 & 463,333 \\
6 Tiang arah Y & 5,3 & 4250 & 463,33 \\
9 Tiang & 5.5888 & 4955,556 & 476,667 \\
12 Tiang arah X & 6,05 & 6291,667 & 463,333 \\
12 Tiang arah Y & 4,967 & 6500 & 470 \\
16 Tiang & 4,687 & 8403 & 476.25 \\
\hline
\end{tabular}

Untuk kondisi Fixed Head:

Tabel 7. Rangkuman hasil dari bending moment kondisi fixed head

\begin{tabular}{cccc}
\hline Jumlah Tiang & Rata-rata Kedalaman $(\mathrm{m})$ & $\begin{array}{c}\text { Rata-rata Load } \\
\text { Maksimum }(\mathrm{kN})\end{array}$ & $\begin{array}{c}\text { Rata-rataBending Moment } \\
\text { Maksimum }(\mathrm{kNm})\end{array}$ \\
\hline 4 Tiang & 6,25 & 7500 & 470 \\
6 Tiang arah X & 5 & 5700 & 445 \\
6 Tiang arah Y & 4,75 & 2667,667 & 853,333 \\
9 Tiang & 4,4222 & 6611,11 & 504,444 \\
12 Tiang arah X & 4,7916 & 6291,667 & 477,9167 \\
12 Tiang arah Y & 5,7166 & 10166,67 & 450 \\
16 Tiang & 4,593 & 10062,5 & 462,5 \\
\hline
\end{tabular}

Berdasarkan analisis yang dilakukan, didapatkan beberapaa saran sebagai berikut:

1. Perlu dilakukan lebih banyak analisis dengan variasi dimensi dan jenis bahan tiang dalam suatu kelompok tiang agar dapat membandingkan lebih banyak data.

2. Perlu dilakukan analisis menggunakan berbagai metode agar dapat membandingkan hasil dari berbagai metode, serta mengetahui metode mana saja yang memberikan hasil terbaik dan yang paling mendekati. 


\section{DAFTAR PUSTAKA}

ATC-40. Seismic Evaluation and Retrofit of Concrete Buildings Volume 1. Applied Technology Council, 1996. Badan Standardisasi Nasional. Tata Cara Perencanaan Ketahanan Gempa untuk Struktur Bangunan Gedung dan Non Gedung (SNI 1726:2012). Badan Standardisasi Nasional, 2012.

Dewobroto, W. Evaluasi Kinerja Struktur Baja Tahan Gempa dengan Analisa Pushover. Universitas Pelita Harapan, 2005.

Liu, JingBo., et al. "Pushover Analysis of Underground Structures: Method and Application". Science China Technological Sciences, vol. 57, no. 2, 2014, pp. 423-437. 